\title{
Body Weight Test Code
}

National Cancer Institute

\section{Source}

National Cancer Institute. Body Weight Test Code. NCI Thesaurus. Code C119795.

A character or string that represents the short code name of the body weight assessment. 